\section{Symptomatic Hyponatremia after Continuous Infusion of Vasopressin: A Case Report}

\section{Bodhrun Naher, Md. Rafiqul Islam*, Sharmistha Ghosal, Khan Lamia Nahid and Md. Rukunuzzaman}

Department of Pediatric Gastroenterology and Nutrition, Bangabandhu Sheikh Mujib Medical University, Dhaka, Bangladesh

\begin{abstract}
Arginine Vasopressin (AVP), also known as antidiuretic hormone, is a endogenously secreted peptide by the posterior pituitary in response to hyperosmolar plasma or systemic hypoperfusion states. Patients in refractory shock associated with severe sepsis, cardiogenic or vasodilatory shock, or cardiopulmonary bypass have inappropriately low plasma levels of AVP ('relative vasopressin deficiency') and supersensitivity to exogenously-administered vasopressin. Low doses of vasopressin can restore vasomotor tone in conditions that are resistant to catecholamines, with preservation of renal blood flow and urine output. This agent exerts its vasoconstriction effects through smooth muscle $\mathrm{V} 1$ receptors and also has antidiuretic activity via renal V2 receptors. This interaction with the renal V2 receptors results in the integration of aquaporin 2 channels in the apical membrane of the renal collecting duct leading to free water reabsorption. Thus, water intoxication with subsequent hyponatremia, although rare, is a potentially serious side effect of exogenous vasopressin administration. We present 1 patient who developed hyponatremia with initiation of vasopressin infusion. The patient required the use of hypertonic saline for more rapid normalization of serum sodium due to her seizure.
\end{abstract}

Keywords: Antidiuresis; Hyponatremia; Vasopressin; Vasodilatory shock; Vasopressors

\section{Introduction}

Arginine Vasopressin (AVP), also known as Antidiuretic Hormone $(\mathrm{ADH})$, is produced in the hypothalamus and secreted into the

*Corresponding author: Md. Rafiqul Islam, Department of Pediatric Gastroenterology and Nutrition, Bangabandhu Sheikh Mujib Medical University, Dhaka, Bangladesh, E-mail: rafiqulislamgsvmc@gmail.com

Citation: Naher B, Islam MR, Ghosal S, Nahid KL, Rukunuzzaman M (2021) Symptomatic Hyponatremia after Continuous Infusion of Vasopressin: A Case Report. J Neonatol Clin Pediatr 8: 077.

Received: April 06, 2021; Accepted: April 12, 2021; Published: April 19, 2021

Copyright: (c) 2021 Naher B, et al. This is an open-access article distributed under the terms of the Creative Commons Attribution License, which permits unrestricted use, distribution and reproduction in any medium, provided the original author and source are credited. circulation through the posterior pituitary gland. Although AVP is secreted in response to stress or shock states, its circulating levels are inappropriately low in patients with refractory hypotension associated with hypovolemia, severe sepsis, cardiogenic shock, or cardiac arrest ('relative vasopressin deficiency') [1,2], which is thought to contribute to the hypotension of shock. In refractory shock, endovascular AVP is depleted [1,3] and exogenous vasopressin exerts profound vasopressor effects even at doses that would not affect arterial blood pressure in normal subjects [4]. Fluid resuscitation and catecholamine support are the standard therapeutic strategy for hemorrhagic shock. However, when the shock is prolonged, the response to both fluid and catecholamine vasopressors can be poor because of acidosis, desensitized receptors, persistent vasodilation and/or NO release [3]. AVP enhanced hemodynamic performance and improved survival, neurologic outcome in animal models in which severe uncontrolled blood loss was induced [5,6]. As with any pharmaceutical agent, the use of vasopressin can result in both beneficial and detrimental effects. In vasodilatory shock, the desirable vasopressor action is counterbalanced by the potential side effects, including water intoxication with subsequent hyponatremia. Here we present 1 patient in which the use of vasopressin resulted in severe hyponatremia.

\section{Case Report}

Moriom, 7 years old girl, weighing $15 \mathrm{~kg}$, was a diagnosed case of obscure GI bleeding, got admitted into BSMMU due to hematemesis and melena with hypovolemic shock. On admission, she was severely pale, anicteric, feeble pulse with tachycardia, CRT $>3$ seconds, BP was $50 / 30 \mathrm{~mm}$ of $\mathrm{Hg}$. She was managed with bolus dose of Normal saline infusion $20 \mathrm{ml} / \mathrm{kg}$ followed by $10 \mathrm{ml} / \mathrm{kg}$ for 2 times, subsequently with whole blood transfusion. She was treated with exogenous Vasopressin infusion $0.3 \mathrm{unit} / \mathrm{kg}$ bolus followed by maintainence dose with $0.2 \mathrm{unit} / 1.73 \mathrm{~m}^{2} / \mathrm{min}$ with $5 \% \mathrm{D} / \mathrm{A}$ saline. Her investigation revealed Hemoglobin $5.4 \mathrm{gm} / \mathrm{dl}$, Total WBC count-7500/ cmm, Platelet count- 2500000/cmm, S.ALT-28 U/L, PT- 13 seconds, INR-1.1, S. Albumin-35g/L, S.Creatinine-0.5, S. Sodium-135mmol/1, S. Potassium $-3.2 \mathrm{mmmol} / 1$, S.Chloride $-98 \mathrm{mmol} / \mathrm{l}$.On $2^{\text {nd }}$ day of treatment, patient had decreased urine output and became drowsy. Her GCS was $13 / 15$. Subsequent electrolyte reports showed S.Sodium-122 mmol/L, S. Potassium-2.9 mmol/L, S.Osmolarity-280mosm/L, RBS$5.4 \mathrm{mmol} / \mathrm{L}$. Patient was managed with $5 \%$ Dextrose in Normal saline infusion. On $3^{\text {rd }}$ day of admission, she developed generalized tonic clonic seizure whish was single episode, persisted for 3 minutes. Her electrolyte reports now showed severe hyponatremia (S. Sodium-110 mmol/l), S.Potassium- 3.3 mmol/1, S.osmolarity-265 mosm/l. Patient was managed with $3 \%$ Sodium Chloride infusion. But her subsequent electrolyte report after calculated correction showed still persisting hyponatremia (S.Sodium- $115 \mathrm{mmol} / \mathrm{L}$ ). So, we thought that this persisting hyponatremia might be due to the exogenous vasopressin infusion and stopped vasopressin infusion. 8 hours after stoppage of vasopressin infusion her electrolyte reports showed dramatic improvement of S.Sodium which was $125 \mathrm{mmol} / \mathrm{L}$ and after 24 hours it was $135 \mathrm{mmol} / \mathrm{l}$. Therefore, it is concluded that Vasopressin use in 
Citation: Naher B, Islam MR, Ghosal S, Nahid KL, Rukunuzzaman M (2021) Symptomatic Hyponatremia after Continuous Infusion of Vasopressin: A Case Report. J Neonatol Clin Pediatr 8: 077.

this patient lead to rapid changes in serum sodium levels concerning for cerebral edema development and it is imperative to monitor serum sodium when a patient is on Vasopressin. After stabilization of patient we did other relevant examination to find out the source of bleeding. Endoscopy of upper and lower GIT revealed normal anatomy, Meckel's scan was negative for ectopic gastric tissue, CT angiography reports were also normal.

\section{Discussion}

Release of endogenous vasopressin from the neurohypophysis can be triggered by several mechanisms including osmotic, nonosmotic (hypotension and decreased effective blood volume), and hormonal stimuli [7-9]. Vasopressin is a nonspecific peptide hormone which exerts its actions through interaction with at least 4 well-known receptors $[10,11]$. Through interaction with $\mathrm{V} 1$ receptors vasopressin exerts the vasoconstrictive effects in vascular smooth muscle. By V1-mediated vasoconstriction of efferent arterioles in the kidneys vasopressin can lead to increased urine output $[12,13]$. On the other hand, vasopressin can also exert antidiuretic effects through interaction with V2 receptors in the renal collecting duct cells. Vasopressin mediated activation of V2 receptors results in a cyclic Adenosine Monophosphate (cAMP) signaling cascade leading to phosphorylation, translocation, and incorporation of Aquaporin 2 Channels (AQP-2) into the apical plasma membrane of the renal collecting duct allowing passive free water reabsorption across an osmotic gradient [10-13]. Water intoxication with subsequent hyponatremia is the potential consequence of V2 receptor activation by exogenous vasopressin administration. However, in clinical trials of vasodilatory shock the incidence of vasopressin-induced hyponatremia has been rare [14-16]. For instance, in the randomized, double-blind, Vasopressin and Septic Shock (VASST) trial comparing vasopressin (0.01-0.03 units/min) versus norepinephrine infusion in 778 adult patients with septic shock (396 randomized to vasopressin), only 1 patient of the 102 developed hyponatremia [17]. Also, there was no observed hyponatremia in the treatment or control groups, in a randomized controlled trial, in pediatric patients with vasodilatory shock given low-dose vasopressin $(0.0005-0.002$ units $/ \mathrm{kg} / \mathrm{min})$ in combination with other vasopressors [16]. A search of the literature did not yield any peer-reviewed publications reporting significant rates of hyponatremia when vasopressin is used for vasodilatory shock. Although, several high rates of hyponatremia have been reported in studies where vasopressin is used for indications other than vasodilatory shock [18-20]. For example, in a pilot safety study, 24 critically ill but hemodynamically stable children were administered either low-dose vasopressin $(0.005$ units $/ \mathrm{kg} / \mathrm{min})$ or normal saline placebo [18]. In all, 8 (66\%) children in the vasopressin group developed hyponatremia versus $1(8 \%)$ in the control group despite a trend toward higher sodium intake in the vasopressin group and no differences in fluid intake between the groups [18]. Increased diuresis and subsequent rise in serum sodium ensued within hours of discontinuing vasopressin. Significant hyponatremia was also observed following high dose ( 0.4 units $/ \mathrm{min})$ of vasopressin administration in a small study comparing somatostatin with vasopressin for thetreatment of acute variceal hemorrhage [19]. Similarly, a case report described the development of severe hyponatremia (serum sodium $116 \mathrm{mEq} /$ $\mathrm{mL}$ from baseline of $141 \mathrm{mEq} / \mathrm{mL}$ ) in a 35 -year-old woman after3 days of vasopressin infusion for variceal hemorrhage at 0.4 units $/ \mathrm{min}$ [20]. Prompt diuresis and subsequent normalization of serum sodium occurred in this patient within 24 hours of discontinuing vasopressin.
Our patient also improved clinically with diuresis and normalization of her seum sodium after discontinuation of exogenous vasopressin.

\section{Conclusion}

Vasopressin-induced hyponatremia, a rare event, can occur when vasopressin is used in patients with vasodilatory shock. Although rare, the case report presented demonstrate that hyponatremia can still manifest. However, more research is needed, if hyponatremia does ensue, additional factors must be assessed for their negative impacton plasma sodium concentrations such as vasopressin dose, patient body weight, adrenal insufficiency, and other medications.

\section{Financial Support}

Self.

\section{Conflict of Interest}

None.

\section{Contribution by Authors}

All authors contributed in the management of case.

\section{References}

1. Landry DW, Levin HR, Gallant EM, Ashton RC, Seo S, et al. (1997) Vasopressin deficiency contributes to the vasodilation of septic shock. Circulation 95: 1122-1125.

2. Polito A, Parisini E, Ricci Z, Picardo S, Annane D (2012) Vasopressin for treatment of vasodilatory shock: An ESICM systematic review and metaanalysis. Intensive Care Med 38: 9-19.

3. Landry DW, Oliver JA (2001) The pathogenesis of vasodilatory shock. N Engl J Med 345: 588-595.

4. Barrett LK, Singer M, Clapp LH (2007) Vasopressin: Mechanisms of action on the vasculature in health andin septic shock. Crit Care Med 35: 33-40.

5. Morales D, Madigan J, Cullinane S, Chen J, Heath M, et al. (1999) Reversal by vasopressin of intractable hypotension in the late phase of hemorrhagic shock. Circulation 100: 226-229.

6. Stadlbauer KH, Wagner-Berger HG, Raedler C, Voelckel WG, Wenzel V, et al. (2003) Vasopressin, but not fluid resuscitation, enhances survival in a liver trauma model with uncontrolled and otherwise lethal hemorrhagic shock in pigs. Anesthesiology 98: 699-704.

7. Sklar AH, Schrier RW (1983) Central nervous system mediators of vasopressin release. Physiol Rev 63: 1243-1280.

8. Goldsmith SR (1988) Baroreceptor-mediated suppression of osmotically stimulated vasopressin in normal humans. J Appl Physiol 65: 1226-1230.

9. Sharshar T, Carlier R, Blanchard A, Feydy A, Gray F, et al. (2002) Depletion of neurohypophyseal content of vasopressin in septic shock. Crit Care Med 30: 497-500.

10. Holmes CL, Patel BM, Russell JA, Walley KR (2001) Physiology of vasopressin relevant to management of septic shock. Chest 120: 989-1002.

11. Maybauer MO, Maybauer DM, Enkhbaatar P, Traber DL (2008) Physiology of the vasopressin receptors. Best Pract Res Clin Anaesthesiol 22: 253-263.

12. Holmes C, Landry D, Granton J (2003) Science review: Vasopressin and the cardiovascular system part 1 - receptor physiology. Crit Care 7: 427434. 
Citation: Naher B, Islam MR, Ghosal S, Nahid KL, Rukunuzzaman M (2021) Symptomatic Hyponatremia after Continuous Infusion of Vasopressin: A Case Report. J Neonatol Clin Pediatr 8: 077.

13. Holt NF, Haspel KL (2010) Vasopressin: A review of therapeutic applications. J Cardiothorac Vasc Anesth 24: 330-347.

14. Obritsch MD, Bestul DJ, Jung R, Fish DN, MacLaren R (2004) The role of vasopressin in vasodilatory septic shock. Pharmacotherapy 24 : 1050-1063.

15. Russell JA, Walley KR, Singer J, Gordon AC, Hébert PC, et al. (2008) Vasopressin versus norepinephrine infusion in patients with septic shock. N Engl J Med 358: 877-887.

16. Choong K, Bohn D, Fraser DD, Gaboury I, Hutchison JS, et al. (2009) Vasopressin in pediatric vasodilatory shock: A multicenter randomized controlled trial. Am J Respir Crit Care Med 180: 632-639.

17. Obritsch MD, Jung R, Fish DN, MacLaren R (2004) Effects of continuous vasopressin infusion in patients with septic shock. Ann Pharmacother 38: 1117-1122.
18. Baldasso E, Garcia P, Piva J, Branco R, Tasker R (2009) Pilot safety study of low-dose vasopressin in non-septic critically ill children. Intensive Care Med 35: 355-359.

19. Kravetz D, Bosch J, Teres J, Bruix J, Rimola A, et al. (1984) Comparison of intravenous somatostatin andvasopressin infusions in treatment of acute variceal hemorrhage. Hepatology 4: 442-446.

20. Melo JA, Lee M, Munoz J, Levine SM (1995) Severe hyponatremia and bradycardia associated withintravenous vasopressin therapy for variceal hemorrhage. J Clin Gastroenterol 20: 266-268. 


\section{Hif}

Advances In Industrial Biotechnology | ISSN: 2639-5665

Advances In Microbiology Research | ISSN: 2689-694X

Archives Of Surgery And Surgical Education | ISSN: 2689-3126

Archives Of Urology

Archives Of Zoological Studies | ISSN: 2640-7779

Current Trends Medical And Biological Engineering

International Journal Of Case Reports And Therapeutic Studies | ISSN: 2689-310X

Journal Of Addiction \& Addictive Disorders | ISSN: 2578-7276

Journal Of Agronomy \& Agricultural Science | ISSN: 2689-8292

Journal Of AIDS Clinical Research \& STDs | ISSN: 2572-7370

Journal Of Alcoholism Drug Abuse \& Substance Dependence | ISSN: 2572-9594

Journal Of Allergy Disorders \& Therapy | ISSN: 2470-749X

Journal Of Alternative Complementary \& Integrative Medicine | ISSN: 2470-7562

Journal Of Alzheimers \& Neurodegenerative Diseases | ISSN: 2572-9608

Journal Of Anesthesia \& Clinical Care | ISSN: 2378-8879

Journal Of Angiology \& Vascular Surgery | ISSN: 2572-7397

Journal Of Animal Research \& Veterinary Science | ISSN: 2639-375

Journal Of Aquaculture \& Fisheries | ISSN: 2576-5523

Journal Of Atmospheric \& Earth Sciences | ISSN: 2689-8780

Journal Of Biotech Research \& Biochemistry

Journal Of Brain \& Neuroscience Research

Journal Of Cancer Biology \& Treatment | ISSN: 2470-7546

Journal Of Cardiology Study \& Research | ISSN: 2640-768X

Journal Of Cell Biology \& Cell Metabolism | ISSN: 2381-1943

Journal Of Clinical Dermatology \& Therapy | ISSN: 2378-8771

Journal Of Clinical Immunology \& Immunotherapy | ISSN: 2378-8844

Journal Of Clinical Studies \& Medical Case Reports | ISSN: 2378-880

Journal Of Community Medicine \& Public Health Care | ISSN: 2381-1978

Journal Of Cytology \& Tissue Biology | ISSN: 2378-9107

Journal Of Dairy Research \& Technology | ISSN: 2688-9315

Journal Of Dentistry Oral Health \& Cosmesis | ISSN: 2473-6783

Journal Of Diabetes \& Metabolic Disorders | ISSN: 2381-201X

Journal Of Emergency Medicine Trauma \& Surgical Care | ISSN: 2378-8798

Journal Of Environmental Science Current Research | ISSN: 2643-5020

Journal Of Food Science \& Nutrition | ISSN: 2470-1076

Journal Of Forensic Legal \& Investigative Sciences | ISSN: 2473-733X

Journal Of Gastroenterology \& Hepatology Research | ISSN: 2574-2566
Journal Of Genetics \& Genomic Sciences | ISSN: 2574-2485

Journal Of Gerontology \& Geriatric Medicine | ISSN: 2381-8662

Journal Of Hematology Blood Transfusion \& Disorders | ISSN: 2572-2999

Journal Of Hospice \& Palliative Medical Care

Journal Of Human Endocrinology | ISSN: 2572-9640

Journal Of Infectious \& Non Infectious Diseases | ISSN: 2381-8654

Journal Of Internal Medicine \& Primary Healthcare | ISSN: 2574-2493

Journal Of Light \& Laser Current Trends

Journal Of Medicine Study \& Research | ISSN: 2639-5657

Journal Of Modern Chemical Sciences

Journal Of Nanotechnology Nanomedicine \& Nanobiotechnology | ISSN: 2381-2044

Journal Of Neonatology \& Clinical Pediatrics | ISSN: 2378-878X

Journal Of Nephrology \& Renal Therapy | ISSN: 2473-7313

Journal Of Non Invasive Vascular Investigation | ISSN: 2572-7400

Journal Of Nuclear Medicine Radiology \& Radiation Therapy | ISSN: 2572-7419

Journal Of Obesity \& Weight Loss | ISSN: 2473-7372

Journal Of Ophthalmology \& Clinical Research | ISSN: 2378-8887

Journal Of Orthopedic Research \& Physiotherapy | ISSN: 2381-2052

Journal Of Otolaryngology Head \& Neck Surgery | ISSN: 2573-010X

Journal Of Pathology Clinical \& Medical Research

Journal Of Pharmacology Pharmaceutics \& Pharmacovigilance | ISSN: 2639-5649

Journal Of Physical Medicine Rehabilitation \& Disabilities | ISSN: 2381-8670

Journal Of Plant Science Current Research | ISSN: 2639-3743

Journal Of Practical \& Professional Nursing | ISSN: 2639-568

Journal Of Protein Research \& Bioinformatics

Journal Of Psychiatry Depression \& Anxiety | ISSN: 2573-0150

Journal Of Pulmonary Medicine \& Respiratory Research | ISSN: 2573-0177

Journal Of Reproductive Medicine Gynaecology \& Obstetrics | ISSN: 2574-2574

Journal Of Stem Cells Research Development \& Therapy | ISSN: 2381-2060

Journal Of Surgery Current Trends \& Innovations | ISSN: 2578-7284

Journal Of Toxicology Current Research | ISSN: 2639-3735

Journal Of Translational Science And Research

Journal Of Vaccines Research \& Vaccination | ISSN: 2573-0193

Journal Of Virology \& Antivirals

Sports Medicine And Injury Care Journal | ISSN: 2689-8829

Trends In Anatomy \& Physiology | ISSN: 2640-7752

Submit Your Manuscript: https://www.heraldopenaccess.us/submit-manuscript 